\title{
Some Lessons on the Rescue of Long-Term Capital Management
}

By Joseph G. Haubrich 


\section{Some Lessons on the Rescue of Long-Term Capital Management}

By Joseph G. Haubrich

This paper reviews the restructuring and recapitalization of Long-Term Capital Management, looking at possible alternatives and paying particular attention to the Federal Reserve's role.

Joseph G. Haubrich is a consultant and economist at the Federal Reserve Bank of Cleveland. He thanks Mark Sniderman and Tom Baxter for helpful comments on earlier drafts.

Materials may be reprinted, provided that the source is credited. Please send copies of reprinted materials to the editor.

Policy Discussion Papers are published by the Research Department of the Federal Reserve Bank of Cleveland. To receive copies or to be placed on the mailing list, e-mail your request to 4dsubscriptions@clev.frb.org or fax it to 216-579-3050. Please send your questions comments, and suggestions to us at editor@clev.frb.org.

Policy Discussion Papers are available on the Cleveland Fed's site on the World Wide Web: www.clevelandfed.org/Research.

Views stated in Policy Discussion Papers are those of the authors and not necessarily those of the Federal Reserve Bank of Cleveland or of the Board of Governors of the Federal Reserve System. 


\section{Introduction}

In September 1998, Long Term Capital Management (LCTM) avoided bankruptcy when a group of its major creditors, meeting at the Federal Reserve Bank of New York, worked out a restructuring deal that recapitalized the firm. The results of this restructuring, and the Federal Reserve's role in it, can be instructive for thinking about the Federal Reserve's role in responding to financial crises.

Much of the reflection on the LTCM crisis has centered on controlling the risk and leverage of unregulated financial firms, raising questions about improving counterparty risk management, regulating hedge funds, and the like. Relatively little reflection has occurred on the causes and consequences of the Federal Reserve's involvement in the matter.

This is unfortunate, because the LTCM episode raises many key issues about the resolution of financial crises: How far should the involvement of the central bank extend, what is the scope of action each of the various players should be responsible for, and what are the costs and benefits of the differing options? Because the Federal Reserve did become involved, though in a way that committed no funds, the possibilities for both greater and lesser involvement were thrown into high relief. By making the various containment options explicit, and evaluating the reasons for taking or not taking those options, a reflection on this episode can provide a template for central bankers facing similar questions in future crises.

\section{Background}

Perhaps the best brief summary of the events surrounding the LTCM crisis comes from Myron Scholes's article, "Crisis and Risk Management" in the May 2000 American Economic Review Papers and Proceedings (Scholes, 2000, p.17), one of the few public statements made by an LTCM partner:

The increase in volatility (particularly in the equity markets) and the flight to liquidity around the world resulted in an extraordinary reduction in the capital base of the firm that I was associated with, Long-Term Capital Management (LTCM). This reduction in capital culminated in a form of negotiated bankruptcy.A consortium of 14 institutions, with outstanding claims against LTCM, infused new equity capital into LTCM and took over it and the management of its assets. They hired LTCM's former employees to manage the portfolio under their direct supervision and with sufficient incentives to undertake the task efficiently.

Although the Federal Reserve Bank (FRB) facilitated the takeover, it did not bail out LTCM. Many debtor entities found it in their self-interest not to post the collateral that was owed to LTCM, and other creditor entities 
claimed to be ahead of others to secure earlier payoffs. Without the FRB acting quickly to mitigate these holdup activities, LTCM would have had to file for bankruptcy-for some, a more efficient outcome, but a far more costly outcome for society. If there was a bailout, it failed:LTCM has been effectively liquidated.

Two rather technical issues have large implications for any discussion about LTCM's bankruptcy. The first was the structure of the partnership: Long-Term Capital Management, L.P., was organized as a Delaware limited partnership, but the fund it operated, Long-Term Capital Portfolio, L.P., was organized as a Caymans Island limited partnership (House Committee on Hedge Fund Operations, 1999, p. 10).This structure complicated any resolution or buyout of the fund, and it is possible that the two entities would have declared bankruptcy in different jurisdictions, adding to the complications and expenses of the proceedings (House Committee on Hedge Fund Operations, 1999, p. 27).

The second technical issue was related to LTCM's large holdings of financial derivatives. Bankruptcy usually triggers an "automatic stay" that prevents creditors from seizing the borrower's assets. Over-the-counter-derivatives contracts are exempt from this provision, however, and in case of bankruptcy, creditors would be able to terminate the contract, taking the collateral for partial payment. Most likely, the creditors would sell the liquid securities, and given the size of LTCM's portfolio, liquidating all these securities could have been very disruptive (House Committee on Hedge Fund Operations, 1999, p. E-6).

\section{Criticism}

The dissatisfaction with the Federal Reserve's role is perhaps best expressed by Kevin Dowd in a CATO Institute paper (Dowd, 1999, p. 1).

The Fed's intervention was misguided and unnecessary because LTCM would not have failed anyway, and the Fed's concerns about the effects of LTCM's failure on financial markets were exaggerated. In the short run the intervention helped the shareholders and managers of LTCM to get a better deal for themselves than they would otherwise have obtained.

The intervention also is having more serious long-term consequences: it encourages more calls for the regulation of hedge fund activity, which may drive such activity further offshore; it implies a major open-ended extension of Federal Reserve responsibilities, without any congressional authorization; it implies a return to the discredited doctrine that the Fed should prevent the failure of large financial firms, which encourages irresponsible risk taking; and it undermines the moral authority of Fed poli- 
cymakers in their efforts to encourage their counterparts in other countries to persevere with the difficult process of economic liberalization.

Other authors have made similar points (Altman, 1998).

These criticisms fall into three main categories: Was the Fed's judgment about the consequences of failure prudent? Was the intervention necessary, or were there viable alternatives? Did the intervention have adverse consequences, specifically, consequences that added to moral hazard?

\section{Was the Intervention Necessary?}

With regard to the wisdom of intervention, Federal Reserve officials have admitted that the decision was a judgment call, justifying their actions as a way to prevent severe negative consequences. In his testimony to the House Banking and Financial Services Committee (House Committee on Hedge Fund Operations, 1998, p. 24), Federal Reserve Board Chairman Alan Greenspan explained:

In situations like this, there is no reason for central bank involvement unless there is a substantial probability that a fire sale would result in severe, widespread, and prolonged disruptions to financial market activity. .... It was the FRBNY's judgment that it was to the advantage of all parties-including the creditors and other market participants-to engender if at all possible an orderly resolution rather than let the firm go into disorderly fire-sale liquidation following a set of cascading cross defaults.

In answering a question from Representative Bruce Vento of Minnesota, Federal Reserve Bank of New York President McDonough responded (House Committee on Hedge Fund Operations, 1998, p. 38): "I think you have to start with the notion that we were really very convinced that the American people would suffer in a way that is not appropriate for them to suffer if LTCM failed." Responding to a question from Representative Barney Frank of Massachusetts, President McDonough remarked: "I am quite confident Congressman Frank, that in the absence of any involvement by the Federal Reserve Bank of New York that Long-Term Capital would have collapsed." (House Committee on Hedge Fund Operations, 1998, p. 44).

The report of the President's Working Group on Capital markets stated "The near collapse of Long-Term Capital Management ("LTCM"), a private sector investment firm, highlighted the possibility that problems at one financial institution could be transmitted to other institutions, and potentially pose risks to the financial system." (House Committee on Hedge Fund Operations, 1998, p. viii). 
This is not to say that a systemic collapse was certain, merely uncomfortably possible. Greenspan, responding to Representative Frank (House Committee on Hedge Fund Operations, 1998, p. 45), said:

The issue was in all of our judgments that the probability was sufficiently large to make us very uncomfortable about doing nothing.

My own guess is that the probability was significantly below 50 percent but still large enough to be worrisome...

At the September 1998 FOMC meeting, President McDonough said "I believe we did the right thing, but I certainly understand why others could say we went a little too close to the edge or we went over the edge." (Federal Open Market Committee, 1998, p. 102).

Alternatives to the Restructuring

\section{The Buffet Offer}

One particular concern was that the Fed intervention either directly or indirectly discouraged a bid from a large investor (Representative Vento remarked, "I don't know why we can't say Mr. Buffet's name here today,' (House Committee on Hedge Fund Operations, 1998, p.37). Patrick Parkinson of the Federal Reserve Board in later testimony (May 6, 1999) acknowledged that it was indeed Warren Buffet (p.18)). This offer apparently would have left the LTCM partners with no stake in the firm, as opposed to the 10 percent stake in the consortium bailout that was eventually accepted. Dowd (1999, p. 5) asserts that "The management of LTCM rejected the offer, and one can only presume that they did so because they were confident of getting a better deal from the Federal Reserve's consortium."

Chairman Leach expressed a similar sentiment at the May 6, 1999, hearing (p.17):

I am very worried about a precedent that has gotten almost no review, and that is that this Fed-led,Treasury-endorsed bailout of Long-Term Capital Management had the effect of putting the United States Government in collusion with a group of private parties against a private party alternative bid, and that is the only rationalization for Government action, was that there was no private alternative on the table. But there was, and a very credible one and one that was every bit as secure as the one that was put together by the Government.

Mr. Parkinson responded (p.17) with "First, we think it is important to remember that there was no Government bailout of LTCM, that as President McDonough testified before 
your committee in October, there were no federal funds put at risk, no promises were made by the Federal Reserve, and no individual firms were pressured to participate."

In his earlier testimony, President McDonough (House Committee on Hedge Fund Operations,1998, p.29) acknowledged the concern about the Fed's intervention reducing the likelihood of LTCM partners taking the Buffet offer. This he denied, and stated (p. 30): "So to conclude Mr. Chairman, if anything, we made it more likely than not that the alternative offer would be accepted." He went on to state that (pp.30-31)

For us the involvement I described of the "bird in the hand is worth two in the bush" is, I think, as close to the edge as any senior central banker should ever go, and may be right at the edge of getting involved in a situation and encouraging an outcome.

I can't imagine that anything that the Long-Term Capital people would have heard would have encouraged them to believe that I was somehow saying in any way, "Why don't you bet on the alternative?"

There is also some controversy about why the Buffet bid was not accepted. Lowenstein (2000, pp. 201-202) says the problem was that the bid was formally structured to purchase the assets of LTCM, the management company, which did not include the portfolio, and that John Mead, an outside lawyer for the group making the bid, withdrew the offer.This seems consistent with the account given by President McDonough (House Committee on Hedge Fund Operations, 1998, p.30):

Several hours later, I was informed by the top officer of a firm that would have been one of the participants in that deal that didn't work, that the deal had not been realized, and that the offer was off the table, and therefore the only game in town, other than a collapse of Long-Term Capital, was what we now call the consortium deal.

\section{Lender-of-Last-Resort Option}

There was, at least conceptually, another option for the Federal Reserve.That was to allow LTCM to fail and then for the Fed to undertake the traditional lender-of-last-resort activities of lending freely on good collateral to banks adversely impacted by the failure. Such an approach could have dealt with the liquidity problems generated by the problems at LTCM, but it is less clear how it would solve the "fire sale" problem in the derivatives market. Franklin Edwards (1999) discusses the advantages of this option, but ultimately argues (p.204) "Was the lender-of-last-resort approach the most efficient way for the Federal Reserve to provide assistance? Almost certainly not."At the FOMC meeting on September 
29, President McDonough addresses this issue explicitly, in effect agreeing with Edwards: "As I saw it, our intervention was preferable to letting the firm collapse in the belief that we were good at damage control." (Federal Open Market Committee, 1999, p.101).

\section{Moral Hazard}

One concern was that the Federal Reserve's involvement extended the too-big-to-fail doctrine. Greenspan and McDonough explicitly denied this in response to a question from Representative Maloney (p.62)

Mr. Greenspan: As far as I am concerned, talking about institutions or such, I say nothing is too-big-to-fail.

Mr. McDonough: I couldn't agree more.

Mr. Greenspan:There is an issue here of too-big-to-liquidate-quickly...

In considering the broader question of increasing moral hazard, not just the too-bigto-fail problem, the two officials indicated that the shift was at best, minor. Greenspan, responding to Representative Bachus (p.52), said: "There are no monies involved here, and indeed what occurred was a group of individuals coming together, recognizing that it was in their self-interest to prevent the cross defaults from occurring and the bankruptcy of LTCM from occurring. I don't see how that has significantly, in a material way, increased moral hazard." Also responding to Representative Bachus, McDonough said (p.53): "The reason I thought it was appropriate or recommended that we get the Federal Reserve Bank of New York involved was because we were in such a chaotic market situation that the risk to the real economy, the real people, was sufficiently high. I agree with the chairman that we did increase moral hazard, but we thought it was appropriate."

A perhaps more subtle form of moral hazard potentially arose not from the initial Federal Reserve Bank of New York intervention, but from future monetary policy. Did the LTCM problem lead to a monetary policy that was easier than it might have been? In reflecting on the matter, the Bank for International Settlements' Committee on Global Financial Systems noted the rate cuts in the fall of 1998, but identified them, particularly the cut at the October 15 meeting, as one of the four major factors that "commenced the healing process" in the international financial system (Bank for International Settlements, 1999, p.9).

Transcripts of the September 29, 1998, meeting show the following. Donald Kohn, in setting out the case for a rate cut, was explicit (Federal Open Market Committee, 1999, p.79):"Questions about the financial soundness of a number of financial firms have intensified in the wake of the near failure of Long-Term Capital Management." But this was the case for a 50 basis point cut, while the committee chose 25 . The "seizing up in financial 
markets" is mentioned by Federal Reserve Bank of Cleveland President Jordan (p.91) as support for easing. Federal Reserve Bank of Richmond President Broaddus (p.90) mentioned "The huge increase in perceived risk in financial markets, if it persists, may well short-circuit the earlier, mainly favorable, impact of foreign developments on U.S. financial conditions. In this new environment, we no longer have that offset. Bob McTeer will be happy to know that I am no longer in favor of tightening monetary policy."

LTCM was mentioned at the October 15 meeting, a conference call, in which the federal funds rate was reduced from 5.25 percent to 5.00 percent, but did not seem to be a major reason for the move. President McDonough (p.9) gave his opinion:"I believe there probably are some skeletons still rattling around closets that have not been revealed yet. We do not know. Even the darkest rumors do not suggest anything of the size or shape or potential magnitude of LTCM."

\section{Academic Work}

A small amount of academic work has looked at the effects of the Federal Reserve's intervention. Using an event-study methodology, Kho, Lee, and Stulz (2000) look at the response of bank stocks to several crises and bailouts. For the case of LTCM, they look at the returns of four banks (those in the Datastream retail banking index) that later attended the meeting at the New York Federal Reserve Bank.They find significantly negative returns for these banks on the days surrounding the announcement of LTCM's losses in early September, which contrasts with positive returns for banks not exposed to LTCM.This suggests that market participants had some knowledge about which firms had exposure to LTCM and which did not. It is unlikely that investors knew the full extent of the exposure, however,because the exposed banks again significantly underperformed other banks following the announcement of the consortium deal. Kho et al. conclude (p. 31): "Our analysis shows that the market distinguishes well between exposed and nonexposed banks when an event occurs....There is therefore no basis for concerns that markets react similarly across banks and that banks have to be protected from the markets. Our evidence raises important questions, especially for those who emphasize the importance of U.S. systemic risks as a motivation for bailouts."

Craig Furfine (2006) obtains some closely related results by looking at the market for overnight unsecured lending between commercial banks (the federal funds market). Furfine argues that when a there is a significant question about a bank's solvency, it is unable to find fed funds at any rate, and it is, in effect, rationed out of the market. Had there been significant concern about solvency in early September, when the news of LTCM's losses first came out, the banks with exposure should have been unable to get funds. Furfine does not find evidence that investors restricted their lending to the nine banks that eventually participated in the LTCM rescue. Thus, while Kho et al's results suggest that 
markets understood that LTCM materially hurt these banks' profits, their solvency was not in question. Once the rescue was announced, the banks did face higher interest rates for unsecured borrowing, suggesting some increase in risk at these banks, and consistent with the negative stock returns noted by Kho et al. Governor Meyer uttered a similar conclusion in testimony on March 24, 1999, "Our reviews indicated and the financial results illustrate that, while the LTCM incident and other episodes over the past two years may have significantly impacted earnings, they did not threaten the solvency of any U.S. commercial banking institution."

Of perhaps greater interest, though, is Furfine's finding that the interest rate charged to large complex banking organizations decreased after the announcement of the LTCM resolution. This indicates a market judgment that these banks became safer. He indicates two possible interpretations. The one is that by revealing themselves as less exposed to LTCM, the trading strategies of these banks were thought safer, whereas before their exposure was perhaps unknown. Or (p.621) "Alternatively, this result suggests that the Fed's action, even though it provided no public money, may have been perceived in the market as an implicit extension of a TBTF [too-big-to-fail] policy."

\section{Lessons Learned}

The Federal Reserve has responded to financial crises in a variety of ways. It has directly lent money to banks, such as the $\$ 45$ billion lent in the aftermath of September 11,2001. It has adjusted regulations, such as the time it relaxed Regulation $Q$ in the wake of the Penn Central commercial paper scare. It has extended the trading hours of the Open Market Desk, such as in the Drysdale Securities affair. And it has, in some cases, done nothing more than watch cautiously. With the collapse of LTCM, financial authorities had to choose between various containment options: doing nothing, orchestrating a recapitalization, or directly intervening. The resolution of LTCM has taught us three practical lessons for an era of increasing concentration among commercial banks, large hedge funds, and emerging private equity firms.

Lesson 1: Context matters. Large losses at a financial firm do not by themselves create a need for Federal Reserve action: there must be a systemic component.

Though by all accounts it was not coincidence, LTCM collapsed when the markets were beset by other shocks. Greenspan, in his statement (p.23) explained:

With credit spreads already elevated and the market prices of risky assets under considerable downward pressure, Federal Reserve officials moved more quickly to provide their good offices to help resolve the affairs of LTCM than would have been the case in more normal times. If effect, the threshold of action was lowered by the knowledge that markets had recently become fragile. 
Furthermore, because of LTCM's complicated structure, the effect of its losses on the market was particularly hard to gauge, making the risk proportionately greater. Again, Greenspan (p.24) remarked:

The scale and scope of LTCM's operations, which encompassed many markets, maturities, and currencies and often relied on instruments that were thinly-traded and had prices that were not continuously quoted, made it exceptionally difficult to predict broader ramifications of attempting to close out its positions precipitately.

Brian Leach, of the oversight committee that unwound LTCM's positions after the recapitalization, told Risk Magazine: "Everybody wanted a haircut because they only saw gross exposure, while internally we saw it as net exposure."

Lesson 2: Details matter.

The large derivative position of LTCM created additional problems. As mentioned above, derivatives have an exception to the usual automatic stay granted after bankruptcy. In the event of default, LTCM's counterparties had the right to sell any of the fund's assets in their control, potentially dumping even more assets onto the market, lowering prices still further. (Edwards, 1999)

That the problem was resolved successfully depended, in a large part, on "the orderly continuation in the risk arbitrage business of the newly recapitalized LTCM" (Bank for International Settlements, 1999, p. 9) which in turn depended on getting the details of the recapitalization right. In the LTCM case it meant retaining the management, giving enough stake in the firm to provide an incentive for efficient liquidation, and bringing in outside oversight.

Even after taking the intermediate step of "providing good offices," the amount and type of moral suasion had to be decided on. Each choice in turn faced trade-offs-what were the costs of doing nothing? What was the probability that markets would seize up? Was there a viable alternative? Would the intervention make further crises more likely? Lesson 3: Look for the minimum effective intervention; or, work with the market, not against it.

Financial markets, despite their problems, are often very efficient. The agreement to recapitalize LTCM resulted from a group of private firms recognizing it was in their interest to infuse more capital.The market again was used to conduct an orderly unwinding of the firm's positions. In fact, there is some evidence that even more reliance could have been placed on the market in the LTCM case. Stock prices and federal funds rates incorporated substantially correct information about exposures to LTCM. Fed intervention, despite its limited character, may have indeed increased moral hazard by increasing the perception of too-big-to-fail. 
Applying these rules takes judgment and cannot be done mechanically.As the financial system evolves, the situation changes. President Geithner, for example, argues (2006) that changes since LTCM have improved the stability and resilience of the financial system, reducing the "probability of systemic events."Those same changes, though, "may amplify the damage caused by and complicate the management of very severe financial shocks." These decisions have to be made quickly, and with imperfect information. In the end, the final consequences may not be apparent until years later. Hopefully, though, keeping the past in mind will make the future that much easier to handle. 


\section{References}

Altman, Roger C. 1998. “Dangerous Bailout,” Washington Post.

Bank for International Settlements, Committee on the Global Financial System. 1999 (October).“A Review of Financial Market Events in Autumn 1998.”

Dowd, Kevin. 1999. “Too Big to Fail? Long-Term Capital Management and the Federal Reserve," Cato Institute Briefing Paper, no. 52.

Edwards, Franklin R. 1999. "Hedge Funds and the Collapse of Long-Term Capital Management,"Journal of Economic Perspectives, vol. 13, no. 2, p. 189-210.

Federal Open Market Committee. 1999. Transcript of the September 29, 1999 meeting. <www.federalreserve.gov/fomc/transcripts/1998/980929meeting.pdf>, accessed January $8,2007$.

Federal Open Market Committee. 1998. Transcript of the October 15, 1998 conference call. <www.federalreserve.gov/fomc/transcripts/1998/981015confcall.pdf>, accessed January 8, 2007.

Furfine, Craig. 2006."The Costs and Benefits of Moral Suasion: Evidence from the Rescue of Long-Term Capital Management,"Journal of Business, vol. 79, no. 2, pp. 593-622.

Geithner, Timothy F. 2006. "Hedge Funds and Derivatives and their Implications for the Financial System," Remarks at the Distinguished Lecture 2006, Hong Kong Monetary Authority and Hong Kong Association of Banks (September, 15, 2006).

House Committee on Banking and Financial Services's Subcommittee on Financial Institutions and Consumer Credit, 1999. Testimony of Governor Laurence H. Meyer at the Hearing on Hedge Funds before the Subcommittee on Financial Institutions and Consumer Credit, Committee on Banking and Financial Services (March 24).

House Committee on Banking and Financial Services. 1998. Testimony of Alan Greenspan at the Hearing on Hedge Fund Operations: before the House Committee on Banking and Financial Services, 105th Congress, 2nd session, (October 1), Serial 105-80.

House Committee on Banking and Financial Services. 1998. Hearing on Hedge Fund Operations before the House Committee on Banking and Financial Services, 105th Congress, 2nd session, Serial no. 105-80. 
House Committee on Banking and Financial Services. 1999. Hearings on the President's Working Group Study on Hedge Funds, 106th Congress, 1st session, Serial no. 106-19.

House Committee on Banking and Financial Services. 1999. Hedge Funds, Leverage, and the Lessons of Long-Term Capital Management:Report of the President's Working Group on Capital Markets (April).

Kho, Bong-chan, Dong Lee, and Rene M. Stulz. 2000."U.S. Banks, Crises, and Bailouts: From Mexico to LTCM," American Economic Review Papers and Proceedings, vol. 90, no. 2, pp. 28-31.

Lowenstein, Roger. 2000. When Genius Failed:The Rise and Fall of Long-Term Capital Management. New York: Random House.

Risk Magazine. 1999. "Risk Managers of the Year," <www.riskpublications.com/ riskawards/riskawards-ltcm.htm.>, accessed January 12, 2007. 